\title{
Psychology in the Brazilian Prison System: An Account of Professional Experience
}

\author{
Luciana Xavier Senra \\ Department of Psychology, Catholic University of Petrópolis, Petrópolis, Brazil \\ Email: senra.lx@gmail.com
}

How to cite this paper: Senra, L. X. (2020). Psychology in the Brazilian Prison System: An Account of Professional Experience. Advances in Anthropology, 10, 61-79. https://doi.org/10.4236/aa.2020.101005

Received: January 18, 2020

Accepted: February 24, 2020

Published: February 27, 2020

Copyright $\odot 2020$ by author(s) and Scientific Research Publishing Inc. This work is licensed under the Creative Commons Attribution International License (CC BY 4.0).

http://creativecommons.org/licenses/by/4.0/

\begin{abstract}
This is a report of the psychologist's professional experience in the context of the Brazilian Prison System. A methodology of the Focus Groups and the content analysis technique were used to address this context from the perspective of nine people deprived of liberty. The theoretical framework for social cognition was adopted to discuss the experience, especially beliefs, stereotypes and prejudices about privation of liberty, crime and drugs (use and trafficking). The experience allowed to investigate, among other indicators, the difficulty of providing adherence of subjects deprived of freedom to psychology work due to beliefs, stereotypes and prejudices related to involvement with crime. The types of individual and group representations resulting from content from characteristics attributed to persons depriving freedom due to crime involving drug trafficking were found. These representations trigger rejection of these people explained in social prejudice from the combination of unfavorable and negative beliefs and feelings. Finally, it was found that the methodology used combined with the theoretical contribution of Social Cognition, can guide the design of research, as well as the guidance and plans of work of the professional performance of the Psychologist in the context of the Brazilian Prison System, which is deficient in this performance.
\end{abstract}

\section{Keywords}

Brazilian Prison System, Stereotype, Psychology, Professional Experience

\section{Introduction}

\subsection{Social Cognition}

Explaining about social cognition, especially about the theme beliefs, stereotypes and prejudices, requires exposure, even if succinct, of the approach to Social Psychology. This is because this discipline is characterized by the multiplicity 
and plurality of theoretical approaches adopted, which are as legitimate references to the production of psychosocial knowledge. However, this characteristic reveals, otherwise, the difficulty of delimiting the object of study or even the various objects of study of this discipline; therefore, apparently, a generic strategy of scope, the study of the relationships that people maintain between themselves and with society or culture in which they are establishing their experiences and individual and collective experiences (Aronson, Wilson, \& Akert, 2015; Ferreira, 2010).

It is important to highlight, the reference of Psychological Social Psychology as a theoretical framework for reading intraindividual processes responsible for the way individuals respond to social stimuli (Ferreira, 2010; Camino \& Torres, 2013). This discipline consists, therefore, in the psychological approach and is based on a scientific interest, which involves "cognition, affection, motivation, decision-making process, learning and conduct, which manifest themselves in social interactions, considering the historically defined socio-cultural situations, which make up the context in which human interactions of every species unfold" (Krüger, 2004: p. 174). In view of this and in accordance with this author, it is essential to address and clarify some of the fundamental concepts for the present study.

According to Pereira (2013: p. 191), it is fundamental for studies involving social cognition the basic premise that "knowledge about the world is an essential element for survival". This understanding, according to the same author, also implies the understanding that the ability to reason about causes and reasons about a given episode or event consists of one of the most important elements for apprehension of human nature. In this sense, social cognition, in addition to establishing a close relationship with cognitive psychology, allows the study of social behavior and human actions from an intraindividual perspective.

Through the adoption of the basic care stemming from the defining social cognition, it is thus possible to conceive it as the processing of social information, thought and knowledge about any "human object", whether an individual (himself, with his motivations, affections and beliefs), groups, roles or institutions, from structures and processes through which the subjects select, interpret, remember and use social information makes evaluations, judgments and decisions. This concept thus denotes stereotyped ways of thinking, explanation of ambiguous social facts, thoughts that give meaning to social interactions, intergroup social contacts, ethnocentrism, prejudice, inferences from partial data, among others (Aronson, Wilson, \& Akert, 2015; Pereira, 2013).

Eysenk (1990) and Fiske and Taylor, (2017) presented the study of social knowledge (structures and contents) and cognitive processes (including acquisition, representation and retrieval of information) provides a key to understanding social behavior and its mediating factors. These studies highlight that social cognition is often marked by apparent and biased errors, which motivated social psychologists to seek and identify why certain people employ stereotypes; that is, a possible mental fallacy or misunderstanding of a social group; a "biased" cog- 
nition of an individual, resulting from factors proposed as "simplicity" of the thought and resulting from creation and social motivation such as authoritarianism.

Nowadays, other authors have sought to broaden this discussion around Social Cognition, such as Fiske and Taylor $(2017 ; 2013)$ consider that social cognition refers to the process by which people think about other people and themselves. It focuses on how people usually think and feel about others. On the other part, the basic cognitive process in social cognition involves perception as a social stimulus (Self, other people or the interaction between both) in different degrees of complexity (Myers, 2014).

In this sense, some studies have shown that using specifically techniques such as the Implicit Associations Test (Greenwald, McGhee, \& Schwartz, 1998), have shown that stereotypical associations can implicitly influence social judgment, even for people who consciously seek to avoid their use (Lai et al., 2016).

These implicit stereotypes provoked questions about an individual's control and responsibility for the implicit effects of stereotypes they consciously reject. We also find evidence that reveals that the nature and persistence of social cognitive aspects, such as racism, discrimination and prejudice and the multiple ways in which they can negatively impact the health of some groups, from policies and practices of access to resources, extending to negative stereotypes, supported by cultural racism that foster harmful psychological responses to health (Fiske \& Taylor, 2017).

With the above-mentioned conceptualization, combined with the applicability of techniques, it tends to potentiate the effectiveness of interventions or at least reduce the personal and socially harmful effects arising from negative beliefs, prejudices and social stereotypes. Moreover, it is from the clear conception that social cognition enables "analysis of small variables, which are generally of an intervening nature, associated with the formation of impressions, social perception, organization of self, social inference, attribution of causality, cognitive consonance, formation and change of attitudes, values, prejudices and social stereotypes" (Krüger, 2004), which will be possible to understand the stereotypes related to the person in compliance with compliance with compliance with compliance with compliance with compliance with compliance with penalty of deprivation of liberty.

In this perspective the study of stereotypes, are typically seen as cognitive structures that contain our knowledge, beliefs and expectations about a social group (Stangor, 2012), for example, people in a situation of compliance with the penalty of deprivation of liberty. The view of stereotypes as mental representations of social categories highlights the similarity between stereotypes and other social and non-social concepts. Stereotypes are typically measured and reported as prototypes, that is, lists of unrelated attributes that vary in typicity, thus finding themselves a growing recognition that stereotypes are also imbued with theoretical and causal knowledge. This can be illustrated, for example, in the fact that black people are stereotyped as poor, slums, devoid of education and with a 
tendency to marginality (Sousa \& Barros, 2012).

It is noteworthy that the understanding of belief is indispensable for understanding the topics addressed in the present work, that is, stereotypes and prejudices. Regarding belief it is possible to say that they consist of an affirmative judgment given by a person, given the experience of their own experience; may manifest itself in an oral or written manner, highlighting symbolic content. In other words, beliefs are mental representations related to cognitions, affections and motivations and, even if it is not derived from scientific evidence, it may also be related to neurophysiological structures and processes, given the findings of neuroscience, especially in the segments of cognitive neuroscience and social neuroscience (Turner, 2014; Kruger, 2013).

Based on Fiske and Taylor (2017) and Aronson, Wilson and Akert (2015) with regard to stereotypes, it is possible to infer about people in situations of deprivation of liberty, that stereotypes relating to them also involve criteria of functions psychological and interrelationship between the multiple schemes of individual cognition, since they are applied to distinct groups, people, facts and attributes. In this understanding provided by the schemes, still according to these authors, social stereotypes are therefore schemes that allude traits or attributes common to the members of a stratum, group or social class; in the case in question, persons deprived of the prison sentence in closed regime in the Association of Protection and Assistance to the Convicts-APAC, part of the prison system.

In illustrative character, stereotypes generally attributed to both the institution and people in deprivation of liberty can be identified in common sense common sense common sense common expressions, such as "good bandit, is dead bandit" and "jail is bandit school". These attributions show evaluation or judgment about someone or any institution; and, once shared as in the case of public opinion and social stereotypes, reveal a person's or group's beliefs about something or another group. That is, a cognitive disposition to adhere to such statements; a mental representation, a cognition accepted by at least one person. It presents an empirical value through propositions openly declared by the individual who communicates them. It is considered the cognitive component of human attitudes and has as characteristic personal or group adherence (Fiske \& Taylor, 2017).

In general, therefore, it should be mentioned that the understanding of beliefs allows the analysis and evaluation of the extent of social agreement and the level of subjective acceptance of stereotypes and prejudices directed at people arrested in compliance with a custodial sentence. This means the possibility of identifying how much and how beliefs on this theme are shared; as well as the need to evaluate the receptivity of these beliefs by their patients in a given group or social context, on a personal and psychosocial level, aiming to reorient methodologies and techniques of intervention in the context in which these people are (Fiske \& Taylor, 2017; Sani \& Gonçalves, 2007).

With regard to social stereotypes and prejudices, based on explicit weightings, it is worth noting that these consist of a collectively shared belief about some 
attribute, characteristic or psychological, moral or physical trait attributed extensively to a human grouping, formed through the application of one or more criteria, such as age, sex, intelligence, morality, profession, marital status, schooling, political formation and religious affiliation (Krüger, 2004).

Both conceptions, of belief and stereotypes, allow us to explain that the latter can be classified into self-stereotypes and hetero stereotypes. The first reveals a direction to the group itself to which it belongs; the second classification, in turn, evidences an assignment that targets a distinct group. Both classifications denote positive or negative valuations, which influence several behaviors in social interaction.

These conceptions when associated with feelings and attitudes (more sophisticated psychological structures), are more complex and configure social prejudices, which have as immediate effect discrimination, that is, an unfair, unequal and unfavorable treatment given to a relationship or social interaction, which can be easily verified in the work contexts (selection of personnel), educational (students with some type of disability), in gender relations and, obviously, the prison system due to crime (Aronson, Wilson, \& Akert, 2015; Karam, 2017; Matsumoto \& Gimenez, 2017). But how to identify them and/or measure them? In a situation of professional activity guided by the use of methodology that is related to scientific research, such as focus groups, it is possible to gather information that illustrates and elects indicators that enable the understanding of the beliefs, stereotypes and prejudices of people in situations of deprivation of liberty.

In this sense, both stereotypes and prejudice constitute and give meaning to information from the environment; they guide behaviors and reveal the quality of the images and attitudes of social groups that interact in a social environment, as well as account of the valence of the identities of the groups involved.

\subsection{Psychologist's Performance in the Brazilian Prison System}

According to Trindade (2016) and Altoé (2001), the performance of psychology in the aforementioned context, in some moments, coincides with their story Hof Psychology in Brazil, since even before the officialization of Psychology as a professional category in 1962, there was the contribution of Clinical Psychologists to the legal environment through criminological examinations and issuance of opinions.

After 1962, it is from the 1980s that the psychologist's work in the prison system is better evidenced, because with the Criminal Execution Law (Lei n. 7210 de 11 de julho de 1984, 1984), in Article 6, it was foreseen the existence of a Technical Classification Commission, responsible for elaborating the individualizing program and accompanying the execution of custodial sentences; more clearly situating the psychologist in the exercise of his duties. The commission would be composed, therefore, by at least two heads of service, a psychiatrist, a psychologist and a social worker. However, even with this prerogative, the work, at first, was still restricted to the issuance of reports and opinions due to the 
permanence of criminological examinations, to the detriment of the proposal to humanize the system, adapting the penalty to the needs of each prisoner (Brito, 1999).

The characteristics cited remain until the end of the 1990s, when with the execution of the penalty of deprivation of liberty under the aegis of the above legislation and complementary decrees and/or that altered the work of psychology in this follow-up also under changes; which led to the need for the Federal Council of Psychology (CFP) to guide the action through guidelines of Resolution 12 of 2011 specific to this context. These directions to work in the prison system contributed, in 2000 by the CFP, to the consolidation of a specialty of Psychology in Brazil, called by Legal Psychology, redirecting, therefore, the psychologist's activities with the legal environment and also in the Prison System, implementing the proposal of humanization of work, mainly through the proposal of mental health assistance of the person deprived of liberty (Afonso \& Senra, 2014; France, 2004; Jacob-Vilela, 1999).

The controversy of the psychologist's performance in the Prison System is not marked only by internal issues to the development of the profession in Brazil. On these lines, it is important to situate the professional performance of psychology with the judiciary, especially in the prison system, from the conception of the need to break with the pattern of professional exercise based on issue of opinions and reports psychological problems, whose purpose, in summary, is the evaluation of the repertoire of conduct characteristic of acts legally demarcated as criminal, especially in the tang of a professional exercise through which the purpose is also to guide and supervise future psychologists. Therefore, although the psychologist's performance is guided by Resolution 12 of 2011 of the Federal Council of Psychology, which gives the regulation of action involving, above all, the respect and promotion of human rights and citizenship; the deconstruction of the concept of crime and understanding of the subjects in historical totality, among other guidelines, is still constantly the target of embargo by agencies such as the Public Prosecutor's Office; and, even so, it is the only reference for guidance of supervised traineeships. These forms of education have had their training and reformulation of practices since the 1990s, aiming, in general and in accordance with the Code of Professional Ethics, to develop "work in respecting and promoting freedom, dignity, equality and the integrity of the human being, supported by the values underpinned by the Universal Declaration of Human Rights” (Resolução CFP n. 010/2005; Lake, Amato, Teixeira, Rovinski, \& Bandeira, 2009).

Therefore, although the psychologist's performance is guided by Resolution 12 of 2011 of the Federal Council of Psychology, which gives the regulation of action involving, above all, the respect and promotion of human rights and citizenship; the deconstruction of the concept of crime and understanding of subjects in historical totality, among other guidelines, is still constantly the subject of embargo by agencies such as the Public Prosecutor's Office; and, even so, is the only reference for orientation of supervised internships. These forms of 
teaching have had their training and reformulation of practices since the 1990s, aiming, in general and in accordance with the Code of Professional Ethics, to develop a "work in respecting and promoting freedom, dignity, equality and integrity of the human being, supported by the values underlying the Universal Declaration of Human Rights" (Resolução CFP n. 010/2005; Lago, Amato, Teixeira, Rovinski, \& Bandeira, 2009).

In view of the said prerogative of the Code of Professional Ethics of Psychology, professional practice in this follow-up as internship supervisor has been scoped, for example, to identify and promote the reformulation of social feelings of a negative, aversive and exclusionary nature, directed or existing among people within prisons, translated into the most diverse types of beliefs and stereotypes, in addition to the legal marker of punishment. These beliefs and stereotypes cover individual and collective dimensions of social interaction, such as: 1) expression of sexuality with regard to sexually transmitted diseases, intimate visits, sexual orientation, affective relationships and sexual crimes; 2) anxiety through family relationships when or not they remain given the situation of the sentence; and 3) mental health with regard to drug use and abuse and the reduction of damage in the prison context. These dimensions were identified from preparatory meetings for the development of the supervised internship with the sentenced themselves, which indicated topics of discussion interest for the focus groups. Specifically in the report of the present experience, this strategy, therefore, was intended to enable not only the internship of undergraduate students in psychology, but also tried to promote a work based on humanization of the fulfillment of the sentence in deprivation of liberty, even if the indicator of overpopulation of the prison system tended to be a difficult for this work (Karam, 2017; Techio, 2011).

\subsection{Brazilian Prison System: Brief Considerations}

Although it does not fall into this text, it is not about the history of the Prison System because it is, of course, a relevant security, especially to the law; it is valid to describe data related to the Brazilian prison population, since undoubtedly tends to be an external factor to psychology, but which interferes in a direction way in the work of the professional, especially in the quality of this work. This is because, in 2014, the Ministry of Justice released data from the National Penitentiary Information Survey, when the Brazilian Prison System had 607.731 people in compliance with the penalty. With the data update in 2016 it went to 726.712, making Brazil the country with the third largest prison population in the world (Ministério da Justiça, 2016). Moreover, according to the same survey, even if the overwhelming majority of prisoners are men (around $85 \%$ to $90 \%$ of total prisoners), when it comes to incarcerated women, the percentage rose about five hundred percent between the years 2000 and 2014, of which, the majority are between 18 and 25 years old and are black. Among the modalities of crimes and crimes that motivated the arrest, the predominance is the involvement or relationship with drug trafficking. 
The above situation, even if it mostly covers data from the prison system directed and by the Secretariats of Security and Social Defense of each State of the Federation, does not bring specifications regarding the Associations for the Protection of the Condemned-APACs, that is, legal institutions of private law, non-profit, which administer Centers for Social Reintegration of prisoners. They have scope to recover the detainee, restructuring the execution of the sentence, keeping the regimes closed, semi open and open, in accordance with the Federal Constitution, with its own Statute protected by the Civil Code, as well as by the Criminal Execution Law. However, data on this modality of prison can be consulted with the Brazilian Fraternity of Assistance to convicts-FBAC, and although they need updating, they also show drugs as the main factor of interference in the process of recovery of the prisoner, either due to chemical dependence or by criminal recidivism. This entity consists of a Civil Association also of Private Non-Profit Law, whose purpose is to bring together and maintain the purpose unit of its affiliates and advise inclusive international APACs (FBAC, 2016; Gonçalves \& Gonçalves, 2012).

The overview of these data is explicit in the endorsement of the logical and common-sense relationship about the association drugs and the prison system. But, moreover, it still raises doubts about what happens, given the data controversy or the non-specification of the origin of the information. In other words, the conclusive conception about the overpopulation of prisons falls on the drug, given the relationship that the more a situation linked to the use, consumption, trade and trafficking is punished, the more likely to solve the problems relevant to chemical and psychoactive substances; however, to the detriment, of course, the configuration of the Prison System and criminal execution, whether public or private (Karam, 2017; Gonçalves \& Gonçalves, 2012). It is worth noting that we intend to make legal premises and questions, perhaps enter a territory of institutional discussion not applicable to the theoretical and technical framework of psychology, especially referring to the theoretical contribution of social cognition. Above all, it is intended to highlight the impacts of these propositions and contexts on people's lives and on the relationships they establish from the situation of incarceration, which is, par excellence, according to Karam (2011) the trigger of motivations, feelings and beliefs of a negative, aversive and exclusionary nature, such as stereotypes, in addition to criminal conduct.

The importance of this experience report is the opportunity to disseminate the work of the Brazilian Psychologist carried out in the context of the country Prison System. Through the study and understanding of the conceived and predominant stereotypes among people deprived of liberty, that the professional can plan the action in order to provide the subjective resignification of these negative conceptions that negative impact in the mental health of these people, one among the human rights highlighted in the Brazilian constitution that, even in a situation of deprivation of liberty, needs to be assured to the person who committed a crime.

In general, it is intended that the work be known by professionals from other 
countries who also demand the performance of the psychologist of the prison system, mainly based on Brazil, one of the countries with the largest prison population in the world.

\section{Methodological Strategy}

\subsection{The Professional Experience}

In this section one intends to report a professional experience of internship supervisor of undergraduate psychology. The exercise of this function occurred with the professionalizing stages of the psychologist's training. The internship included: demarcation of the guiding theoretical framework of the themes contemplated; orientation, planning and development of activities; the evaluation of such activities for the target public, which, in this case, were persons deprived of liberty serving time in closed regime of the Prison System of the State of Minas Gerais. The supervision of the internship, directed to students in the completion phase of the course, occurred in the years 2016 and 2017, during four school periods of undergraduate psychology, met the requirements of the discipline of Health Psychology, which with theoretical orientation from Social Psychology and Social Cognition, to study, investigate and direct interventions, involving topics such as beliefs, behaviors, attitudes, stereotypes and prejudices, which could relate to the context of the health care.

It is important to highlight that for the measurement of the variables of the present study, it would be recommended to use an instrument such as the Implicit Association Scan Test. However, according to the rules of legal operation of the Brazilian Prison System, the use of this type of testing can only be used by the psychology professional when there is a judicial determination. This shows, in advance, one of the limitations of experience in reporting in this article. However, it also highlights the need to ethically safeguard the relationship between psychology and the judiciary.

\subsection{Focus Groups: The Professional Performance of the Psychologist in the Brazilian Prison System}

Focus Groups consist of the use of a group interview, which serves specific purposes in each investigation. It is noteworthy, however, that it is not about approaching individuals in the same physical space, since it has theoretical-methodological foundations in group theories and social psychology (Minayo, 1999). This initial description requires a very brief context to make about the origin of the technique, in order to clarify the adoption of the technique within the scope of the supervised internship presented here.

The emergence of focus groups occurred in the 1950s, when Robert Merton and Paul Lazarus field evaluated the responses to a radio program, given the difficulty of people to express opinion about films and other modalities of programs. After this first experiment, Merton used with the army to evaluate the training, a work that resulted in the publication of a book entitled Focus Group 
(Roso, 1997; Gondin, 2002).

From this understanding, although the focus groups have undergone alteration of the initial technique due to the incorporation of several theoretical contributions on groups, the matrix objective is to produce data; or, more specifically, reveal the perceptions of the participants of a group regarding a topic, theme or subject under discussion, preserving the character of the data collection technique for qualitative investigations, contextual and group evaluation and subsequent decision-making on that same context with regard to other possibilities for intervention (Gondim, 2002; Gomes \& Barbosa, 1999).

Considering the objective of the focus group, it is also important to highlight that this technique allows to measure a professional experience as a researcher, since in addition to access to data, it can observe the interactions and all characteristics of the group process, that is, information, perceptions, individual and collective representations arising from this group interaction and regarding a given theme. This allows to achieve the format and physical support necessary for its objectification, providing the professional supervisor of internship in psychology a positioning of attentive and critical interlocutor, which tends to be fundamental in a context such as the prison system, marked by stereotypes and prejudices (Kruger, 2013; Torres \& Camino, 2013; Kind, 2004).

In accordance with these considerations, the focus groups performed through the supervised internship of psychology graduation with the Association of Protection and Assistance to the Convicts-APAC in the state of Minas Gerais, Brazil, aimed to information and perceptions about the situation of deprivation of liberty in the perspective and language of people in compliance with sentence in closed regime of the Prison System in the above state. It is noteworthy that APAC is a legal entity of private, non-profit law, which manages Social Reintegration Centers for prisoners, which aims to recover the detainee, restructuring the execution of the penalty in a humanized way, ensuring rights human rights and health conditions; keeping the regimes closed, semi-open and open, according to the Federal Constitution; and has its Statute protected by the Civil Code, as well as by the Criminal Enforcement Law (FBAC, 2016; Faria, 2011).

The APAC is a partner institution of a private Psychology College in the interior of the State of Minas Gerais, in which the internship was held had, between the school periods of 2016 and 2017, fifty-four convicts in the closed regime; thirty-eight in the semi-open regimen and eight of the open, all male, aged 18 to 63 years and with sentences of various convictions according to the type of regime of compliance with penalty. Institutional activities involved dawn with breakfast and religious rites, lunch and dinner meals. Among these, work and educational activities were performed, monitored technically and professionally. In addition, the convicts had legal assistance for procedural follow-up; social, medical and psychological assistance. These activities and daily life were subjected to supervision of the so-called Community Security Council-CCS, which was chaired by the convicts and a member of the administrative management of the institution and in case of transgression and/or non-compliance with activi- 
ties and schedules, the convict was deprived of leisure activities. It is noted that in the case of transgressions involving the use of low-slang words and assaults directed at other people, the convict was reappointed to the Common Prison System, therefore expelled from the APAC model of compliance with deprivation of liberty penalty (FBAC, 2016).

The supervised internship in Psychology of a private institution course, having adopted all Ethical and Professional Care in accordance with the Code of Professional Ethics of the Brazilian Psychologist, and with the institutions involved, was included in the schedule of psychological assistance of APAC and carried out with those convicted in the Closed Regime at the request of the institution, being therefore directed to the 54 persons of the closed regime, aged between 18 and 63 years of age, all sentenced to more than ten years of deprivation of liberty for recidivism of crimes and/or heinous crimes. The internship was planned with two moments from a previously established theme, which addressed the use of psychoactive substances (Resolução CFP n. 010/2005; Resolução CFP n. 12/2011). The initial moment consisted of the composition of groups for which dynamics were performed that stimulated the interaction between the members, but above all the adherence of the proposal for the composition of the groups and, in a second moment, the focus groups were employed. This procedure was adopted given the difficulty of establishing reliability between the psychology professional and the people arrested, since they tend to conceive this professional as the one who can contribute to the stay in prison, when submitted to psychological evaluation (Brandão \& Baptista, 2015; Gomes \& Barbosa, 1999).

After the initial procedure mentioned, the group planning occurred, which involved: 1) the survey of demands and screening for composition of groups with even for focal themes or achievement of dynamics; 2) the election of themes, training of mediators and rapporteurs, drawing up the axes of discussion and delimitation of the number and duration of the meetings; and 3) the composition of groups of up to thirteen members, totaling four groups. This composition was random among the fifty-four prisoners' members of the closed regime, considering the days and times for each group, which were Tuesdays, Wednesdays and Thursdays, with one hour and thirty minutes long.

The themes listed for the focus groups themselves were prison, expression of sexuality and family context; drugs, crime and deprivation of liberty; and drugs and psychological problems. For each theme, some questions were elaborated to start, stimulate, maintain discussion among members and to incite reflection in relation to the conceptions of the future, after the time has been fulfilled. In the group with up to 13 people, the topics mentioned were discussed in up to three meetings for each, during which the supervising teacher acted as mediator, a student as an auxiliary mediator and contextual observer and two rapporteur students. This strategy of reporting in a manuscript way was adopted because it is an institution for compliance with the penalty of deprivation of liberty, where it is not possible to use electronic and/or audiovisual instruments to record and 
subsequent transcription.

The questions relating to prison and the family context were: 1) what is it like to be imprisoned for you and your family? 2) how is the relationship with an intimate partner and family members after entering prison?; and 3) what are the types of relationship problems and family members existing as a result of the arrest? The issues relevant to crime, drugs and deprivation of liberty consisted of: 1) what is it like to be involved with crime? 2) drugs and trafficking are the predominant reason for deprivation of liberty, how do they understand and relate to drugs? and 3) is there compensation in crime? What? The third theme, which involved drug use and psychological problems covered questions such as: 1) what types of drugs and purpose of use? 2) what types of problems, in addition to illegality were perceived? 3) How does it feel having to have to fully discontinue use? What kind of problems do you experience? The adoption of three questions for each theme aimed to systematize the mediation time, as well as to provide the speech of all people in the focus group. It is worth noting that, both for the thematic discussion itself and for the closure, that the group was prepared through presentation dynamics and "icebreaker"; as well as a dynamics of integration, aiming to establish a good relationship between people and soften the tense context that marks the prison environment.

Regarding the procedures after the groups, it is emphasized that discussions and analyses were necessary involving the discernment between participants and moderator's perceptions; the appreciation of discussions and themes; and, adequacy of mediation. It is worth mentioning that in this report these procedures refer to both people in deprivation of liberty and supervised students. Finally, the focus group technique required the analysis of the results, to verify whether there was coherence of the results obtained with the objectives set for the feasibility of the group, in addition to listing indicators that will enable future decision-making for assistance and intervention in a similar context and even if the focus group is not the methodology adopted, that the elements established guide other methods. For the analysis of the information was used the Content Analysis, which allows the survey, the objective and systematic description of the manifest content of communication, enabling the inference and interpretation of knowledge related to the conditions of these messages, such as perceptions, representations, beliefs, stereotypes and prejudices (Bardin, 2016).

\section{Results and Discussions}

The data determined through the realization of the focus groups were unified, since there were four groups involving the themes related to sexuality, family relationships and the context of prison; crime, drugs and deprivation of liberty, and psychological problems arising from the use and sudden cessation with the fulfillment of sentence. After the unification and general appreciation of this material, the floating reading was performed for objective description and systematization of the contents. These systematizations, combined with previously 
delimited thematic axes, made it possible to enumerate categories for content analysis, which were: 1) beliefs of sexuality, family, drugs and imprisonment; and 2) stereotypes and prejudices of prison for crime relating to the use and trafficking of illicit drugs.

It is interesting to mention that categories A and B were delimited by the calculation of content from the guiding issues of the discussions of the focus groups, as can be observed in Table 1 . These contents are illustrated by speeches from some of the participants identified in this text by $\mathrm{S}_{1}, \mathrm{~S}_{2}, \mathrm{~S}_{3}, \mathrm{~S}_{4}, \mathrm{~S}_{5}, \mathrm{~S}_{6}, \mathrm{~S}_{7}, \mathrm{~S}_{8}$ and $S_{9}$.

The set of questions that triggered in the category of analysis A, allowed, during the focus groups, to list answers such as: $\left(S_{1}\right)$ "is buried alive, without the right to wake, without family and everyone mocking the dead"; $\left(S_{2}\right)$ "it's saber what passes an indigent, homeless man, because it is not seen by anyone, but inside the cage, different from the past I had, that everyone want to see"; $\left(\mathrm{S}_{3}\right)$ "being stuck is that for me freedom was bad before, because now I'm stuck and Know that I didn't know what is free... And... Oh... Who's out there, you think you know, but you don't know"; and $\left(S_{4}\right)$ "after you get in here, you don't have the one the woman's waiting for, who's going to pay the bills? Will she expect me to be entitled to intimate partner relationship? What if air fails? Ter companion or companion in here, only if ghost really air, if not, some". These placements on what it's like to be deprived of freedom for you, for the family and intimate partner, show beliefs that being deprived of freedom is to be a living dead person; of being an invisible person exposed in prison; or that in order to know what freedom is, you must lose it.

These premises denote an important element of beliefs: mental representation with symbolic content that, in this case, is the meaning of being deprived of liberty both from the perspective of the condemned and what this supposes to be the perspective of the people with whom he relates, that is, the family and the intimate partner. It is also evidenced the way they think about the prison system, attributing to it the concrete symbolism of deprivation of liberty and the impact of representativeness on the lives of people directly and indirectly involved in

Table 1. Categories of analysis of the contents calculated in the focus groups.

\begin{tabular}{|c|c|}
\hline $\begin{array}{c}\text { Category A } \\
\text { Beliefs about sexuality, family, } \\
\text { drugs and imprisonment }\end{array}$ & $\begin{array}{l}\text { Category B } \\
\text { Stereotypes and prejudices about prison, } \\
\text { crime and illicit drug use and trafficking. }\end{array}$ \\
\hline Analysis units & Analysis units \\
\hline $\begin{array}{l}\text { - perception of the private person of liberty } \\
\text { and the family member about prison }\end{array}$ & - involvement and compensation of crime \\
\hline $\begin{array}{l}\text { - relationship with an intimate partner and } \\
\text { family members after deprivation of liberty; }\end{array}$ & $\begin{array}{l}\text { - } \quad \text { relationship with drugs before } \\
\text { and after deprivation of liberty }\end{array}$ \\
\hline $\begin{array}{l}\text { - } \quad \text { types of relationship and family } \\
\text { problems after deprivation of liberty }\end{array}$ & $\begin{array}{l}\text { - use, type, problems and interruption } \\
\text { of drug use with deprivation of liberty }\end{array}$ \\
\hline
\end{tabular}

Source: Own authorship based on Bardin (2016). 
criminal responsibility, the family and the intimate partner, which is the commitment of expression and affective relationship and reliability. All these elements explained in beliefs lead to an inference of another component - motivation, because in the face of a predominantly negative conception, the motivation for the change and genuine recovery of the prisoner, tend to be compromised (Sani \& Gonçalves, 2007).

The questions concerning category $\mathrm{B}$ allow the purpose of demonstrating content expressed by the participants of the focus groups consistent with stereotypes and prejudices attributed to people in situations of deprivation of liberty. The first question, about what it is like to be involved with crime, explains content such as: $\left(\mathrm{S}_{5}\right)$ "crime has no return, no; just gone. And those who live in this life, are no longer alive, and you are dead, because if you are on the street is marginal, you can not appear; if you are trapped, it appears because you do not know live". This account contains elements of mental representation that illustrate the social categorization expressed in the affirmative sentence "good bandit is dead bandit". That is, the moral attribute of social stereotypes directed to those in deprivation of liberty, given the collective social perception about what it is like to be a person who committed crime and being plucked (Dias, Machado, Gonçalves, \& Manita, 2012; Pereira, Dantas, \& Alves, 2011; Sani \& Gonçalves, 2007).

The questioning of how they understand the involvement with illicit drugs, either by use or trafficking, revealed psychological characteristics usually shared by both people in deprivation of liberty and by society. In other words, through speeches such as $\mathrm{S}_{6}$, stating that "the drug, one way or another, using or selling, gives status; with it you can have everything, and even tame death"; or that of $\mathrm{S}_{7}$, highlighting that "drug is not bad, bad is the way where it takes you, because either you are drugged or you drug others, is a drug dealer", found the association of social stereotypes with negative feelings, thus constituting a more complex characteristic, called prejudice, which, in turn, tends to an immediate effect, discrimination as with a person sentenced in Brazil (Karam, 2017, 2011; Fiske \& Taylor, 2017; Pereira, Dantas, \& Alves, 2011).

The other reports illustrate category B (stereotypes and prejudices of people in prison for crime related to the use and trafficking of illicit drugs). These reports explained the assessment of crime and crime by the members of the focus groups; as well as the enumeration of typology and the motivation for drug use and the problems triggered by this involvement, not only with regard to the impacts of use to health, but also about the problems of illegality. It is important to highlight that the evaluation of crime and crime by prisoners was a theme proposed by them in the course of the presentation of the proposal for the realization of focus groups.

The assessment and assessment of crime and crime in the context of deprivation of liberty was provided by the questions "is there compensation in crime? Which?", which brought the talks like $S_{8}$ 's: "If I say the crime doesn't pay off, I'm 
going to be lying. Crime pays off a lot! It gives status, power (...) hold gun, money, have gold cord, branded clothing and perfume to have woman... I'm going to say it doesn't make up for it? Only if I'm silly!" This type of positioning was corroborated by another prisoner. $S_{9}$, for example, added: "Crime gives black and the poor, which State does not give... kind of like this... the State, along with the companies, makes everyone who has no cute face, marginal, bandit; leaves no black people, ugly and poor nor works in shopping!".

These considerations show an important characteristic of social stereotypes, which consists of an erroneous, defective or rigid generalization of the social world, which often do not coincide with reality and is used to justify intergroup conduct (Fiske \& Taylor, 2017; Techio, 2011). In the case in question, criminal conduct and the crime itself, as S8 and S9 said, which led them to the situation of compliance with the deprivation of liberty penalty. That is, they generalize by attributes and characteristics related to socioeconomic status, ethnicity and aesthetics, with the statement that poor, black and considered ugly people are criminal and/or marginal.

About the type, use and problems pertinent to the drugs reported by prisoners, it was possible to note, related to the use, the predominance of alcohol and tobacco. Regarding these drugs (lawful), the prisoners mentioned health difficulties, mainly due to abstinence due to sudden interruption given the entry into the prison system. Problems of concentration and anxiety were mentioned mostly. It is important to emphasize about tobacco that, in the APAC prison system, cigarettes have no prohibited but limited use, which leads to a compulsory reduction in use, and may provide the occurrence of situations such as those reported also by $\mathrm{S}_{9}$ :

“after I've reduced my cigarette, I get more nervous, more short dread, lose patience ... then you see... says the drug problem is powder only (cocaine), marijuana (cannabis), crack, trafficking... But and the companies like Souza Cruz, Ambev, they self-drugs in the same way, it's bad for health in the same way and what's the difference? The difference is that the drug I sell on the hill only gives profit me, it's dirty money; theirs is clean, it's tax pay every time I buy a pack of cigarettes and employs people, but it's trade the same way mine! Their trade name is a company, it's legal; The name of my trade, it's trafficking, it's a crime and it put me in jail. But if it was nice, I'd employ a lot of people too, and I bet it would reduce health problems. The bandit, the criminal is the poor and the black one like me. What are you wrong with?"

The report cited finally evidences the social perception inherent to drugs (lawful or not), crime and deprivation of liberty, which explains "stereotypical attributes that are automatically associated with schemes stored in memory", that is, that drugs are only illicit drugs and that alcohol and tobacco are harmful chemicals; as well as that bandit and criminal are poor and black people, given this quite peculiar to the Brazilian reality (Techio, 2011: p. 27; Gonçalves \& 
Gonçalves, 2012). From these schemes, inferences are made that go beyond the information available, such as the impacts on people's attitudes and actions in the context of group interaction, which allow allude not only to the content of stereotypes, to negative feelings and beliefs that characterize social prejudice, but also to the problem around legality/illegality and/or criminalization and/or decriminalization of drug use, a theme that goes beyond the problem of this text, given the above reports (Fiske \& Taylor, 2017; Karam, 2017; Valois, 2016).

\section{Conclusion}

The work of internship supervisor regarding the beliefs, stereotypes and prejudices of people in situations of deprivation of liberty consisted in the use of the focus group technique combined with a brief content analysis according to Bardin's criteria (2016). Through this strategy, it was possible to identify and demonstrate, from the perspective of Social Cognition, the types of individual and group representations that evidence content from characteristics attributed to a grouping of people, such as those in deprivation of liberty due to crime involving or not drug trafficking; that culminate in rejection of these people, explained in social prejudice, due to the unfavorable combination of negative beliefs and feelings.

In addition to these evidences, it was possible to verify that the methodology used together with the theoretical contribution of Social Cognition can act as an indicator of guidance for research design, as well as work plans for the psychologist's professional performance in the context of the Prison System and/or directed to people directly and indirectly affected by the representations arising from the stereotypes and prejudices attributed to them. It is important to emphasize, therefore, that this work did not intend to exhaust the discussions pertinent to the theme and to the public related to it, but aimed to incite the reflection and interest in the subjects addressed by the said theoretical contribution.

Finally, it is important to emphasize that discussions about the complex and difficult professional performance of the Brazilian psychologist in the prison system are not exhausted in this article. This is not a professional experience that aims to be a model of performance in psychology, since it contains significant limitations regarding the absence of an instrument for measuring implicit variables, as defined in the theoretical framework of research in social cognition. In addition, the present experience report aimed primarily to incite reflections and give visibility to the psychologist's work in the Brazilian prison system, as well as the concerns and stereotypes suffered by people deprived of liberty, signaling the importance of psychology in mental health care as a human right of people in the context of prisons.

\section{Conflicts of Interest}

The author declares no conflicts of interest regarding the publication of this paper. 


\section{References}

Afonso, L. A., \& Senra, L. X. (2014). Panorama histórico da regulamentação da Especialização da Psicologia Jurídica no Brasil. https://www.psicologia.pt/artigos/ver_artigo.php?codigo=A0858

Altoé, S. (2001). Atualidade da Psicologia Jurídica. http://biblioteca.cejamericas.org/bitstream/handle/2015/1400/psicologia_juridica.pdf?s equence $=1$ \&isAllowed $=y$

Aronson, E., Wilson, T. D., \& Akert, R. M. (2015). Psicologia Social (8th ed.).

Bardin, L. (2016). Análise de Conteúdo. Lisboa: Edições 70.

Brandão, E. M., \& Baptista, M. N. (2015). As Demandas da Avaliação Psicológica no Contexto Judiciário e a Interação com o Sofrimento e a Violência. In L. M. Lourenço, \& L. X. Senra (Eds.), Violência e Agressividade: Perspectivas psicossociais e educacionais (cap. 7). Curitiba-PR: Juruá.

Brito, L. M. T. (1999). Anotações sobre Psicologia Jurídica. Psicologia: Ciência e Profissão, 32, 194-205. https://doi.org/10.1590/S1414-98932012000500014

Camino, L., \& Torres, A. R. (2013). Origens e desenvolvimento da Psicologia Social. In L. Camino, A. R. R. Torres, M. E. O. Lima, \& M. E. Pereira (Eds.), Psicologia Social: Temas e teorias (2nd ed., pp. 31-108). Brasília: Techno Politik.

Dias, A. R., Machado, C., Gonçalves, R. A., \& Manita, C. (2012). Repertórios interpretativos sobre o amor e as relações de intimidade de mulheres vítimas de violência: Amar e ser amado violentamente? Análise Psicológica, 30, 143-159.

https://doi.org/10.14417/ap.539

http://www.scielo.mec.pt/scielo.php?script=sci_arttext\&pid=S0870-8231201200010001 2\&lng=pt\&tlng=en

Eysenck, M. W. (1990). The Blackwell Dictionary of Cognitive Psychology. Cambridge, MA: Blackwell Reference.

Faria, A. P. (2011). APAC: Um Modelo de Humanização do Sistema Penitenciário. In Âmbito Jurídico, Rio Grande, XIV (87).

http://www.ambito-juridico.com.br/site/index.php?n_link=revista_artigos_leitura\&arti go_id=9296

Ferreira, M. C. (2010). A psicologia social contemporânea: Principais tendências e perspectivas nacionais e internacionais. Psicologia: Teoria e Pesquisa, 26, 51-64.

http://www.scielo.br/pdf/ptp/v26nspe/a05v26ns.pdf https://doi.org/10.1590/S0102-37722010000500005

Fiske, S. T., \& Taylor, S. E. (2017). Social Cognition-From Brains to Culture (3rd ed.). London: SAGE Publication Ltd.

Fiske, S. T., \& Taylor, S. E. (2017). Stereotyping: Cognition and Bias. In S. T. Fiske, \& S. E. Taylor (Eds.), Social Cognition-From Brains to Culture (3rd ed.). London: SAGE Publication Ltd.

Fiske, S., \& Taylor, S. E. (2013). Social Cognition: From Brain to Culture (2nd ed.). Thousand Oaks, CA: Sage Publications. https://doi.org/10.4135/9781446286395

France, F. (2004). Reflexões sobre Psicologia Jurídica e seu panorama no Brasil. Psicologia: Teoria e Prática, São Paulo, 6, 73-80.

Fraternidade Brasileira de Assistência ao Condenado FBAC (2016). Elementos Fundamentais do Método APAC.

http://www.fbac.org.br/index.php/pt/institucional/metodo-apac

Gomes, M. E. S., \& Barbosa, E. F. (1999). A Técnica de Grupos Focais para Obtenção de Dados Qualitativos. https://doi.org/10.5935/1415-2762.20160012 
Gonçalves, L., \& Gonçalves, R. (2012). Agressividade, estilo de vida criminal e adaptação à prisão. Psicologia USP, 23, 559-584. https://doi.org/10.1590/S0103-65642012005000013

Gondin, S. M. G. (2002). Grupos Focais como técnica de investigação qualitativa: Desafios metodológicos. Paidéia (Ribeirão Preto), 12, 149-161. https://doi.org/10.1590/S0103-863X2002000300004

Greenwald, A. G., McGhee, D. E., \& Schwartz, J. L. K. (1998). Measuring Individual Differences in Implicit Cognition: The Implicit Association Test. Journal of Personality and Social Psychology, 74, 1464-1480. https://doi.org/10.1037/0022-3514.74.6.1464

Jacob-Vilela, A. M. (1999). Os primórdios da psicologia jurídica. In L. M. T. Brito (Ed.), Temas de Psicologia Jurídica (pp. 171-185). Rio de Janeiro: Relumé Dumará.

Karam, M. L. (2011). Psicologia e sistema prisional. Revista EPOS, 2. http://pepsic.bvsalud.org/scielo.php?script=sci_arttext\&pid=S2178-700X201100020000 $6 \& \operatorname{lng}=\mathrm{pt} \& \ln \mathrm{g}=\mathrm{pt}$

Karam, M. L. (2013). Direitos humanos, laço social e drogas: Por uma política solidária com o sofrimento humano. In Conselho Federal de Psicologia. Drogas, direitos humanos e laço social (pp. 33-52). Brasília: CFP.

Karam, M. L. (2017). Considerações sobre as políticas criminais, drogas e direitos humanos. In M. Dalla Vecchia, T. M. Ronzani, F. S. Paiva, C. B. Batista, \& P. H. A. Costa (Eds.), Drogas e direitos humanos: Reflexões em tempos de guerra às drogas (396 p). Porto Alegre: Rede UNIDA.

Kind, L. (2004). Notas para o trabalho com a técnica de grupos focais. Psicologia em Revista, 10, 124-136.

http://portal.pucminas.br/imagedb/documento/DOC_DSC_NOME_ARQUI200412131 15340.pdf

Krüger, H. (2004). Cognição, estereótipos e preconceitos sociais. In M. E. Pereira, \& M. E. O. Lima (Eds.), Estereótipos, preconceitos e discriminação: Perspectivas teóricas e metodológicas (pp. 23-40). Salvador: Editora da Universidade Federal da Bahia.

Kruger, H. (2013). Ideologia, sistema de crenças e atitude. In L. Camino, A. R. R. Torres, M. E. O. Lima, \& M. E. Pereira (Eds.), Psicologia Social: Temas e teorias (2nd ed., pp. 263-310). Brasília: Techno Politik.

Lago, V. M., Amato, P., Teixeira, P. A., Rovinski, S. L. R., \& Bandeira, D. R. (2009). Um breve histórico da psicologia jurídica no Brasil e seus campos de atuação. Estudos de Psicologia, 26, 483-491. http://www.scielo.br/pdf/estpsi/v26n4/09.pdf https://doi.org/10.1590/S0103-166X2009000400009

Lai, C. K., Skinner, A. L., Cooley, E., Murrar, S., Brauer, M., Devos, T., Calanchini, J. et al. (2016). Reducing Implicit Racial Preferences: II Intervention Effectiveness across Time. Journal of Experimental Psychology General, 145, 1001-1016. https://doi.org/10.1037/xge0000179

Lei n. 7210 de 11 de julho de 1984 (1984). Institui a Lei de Execução Penal. Brasília.

Matsumoto, S. A. E., \& Gimenez, G. (2017). Considerações Sobre Drogas, Sistema Carcerário E Criminologia Crítica. In M. Dalla Vecchia, T. M. Ronzani, F. S. Paiva, C. B. Batista, \& P. H. A. Costa (Eds.), Drogas e direitos humanos: Reflexóes em tempos de guerra às drogas (396 p.). Porto Alegre: Rede UNIDA.

Minayo, M. C. de S. (1999). O desafio do conhecimento: Pesquisa qualitativa em saúde (6th ed.). São Paulo: Hucitec.

Ministério da Justiça (2016). Levantamento Nacional de Informaçóes Penitenciárias-INFOPEN. 
http://depen.gov.br/DEPEN/noticias-1/noticias/infopen-levantamento-nacional-de-inf ormacoes-penitenciarias-2016/relatorio_2016_22111.pdf

Myers, D. G. (2014). Social Psychology (10th ed.). New Delhi: Tata McGraw Hill.

Pereira, M. E. (2013). Cognição Social. In L. Camino, A. R. R. Torres, M. E. O. Lima, \& M. E. Pereira (Eds.), Psicologia Social: Temas e teorias (2nd ed., pp. 191-262). Brasília: Techno Politik.

Pereira, M. E., Dantas, G., \& Alves, M. V. (2011). Estereótipos, automatismos, controle e a identificação de armas e ferramentas em diferentes contextos: Resultados preliminares. In E. M. Techio, \& M. E. O. Lima (Eds.), Cultura e produção das diferenças: Estereótipos e preconceitos no Brasil, na Espanha e Portugal (pp. 77-106). Brasília: Technopolilitik.

Resolução CFP n. 010/2005. Código De Ética Profissional Do Psicólogo. Conselho Federal de Psicologia.

http://site.cfp.org.br/wp-content/uploads/2012/07/codigo-de-etica-psicologia-1.pdf

Resolução CFP n. 12/2011. Regulamenta a atuação da(o) psicóloga(o) no âmbito do sistema prisional. Conselho Federal de Psicologia.

https://atosoficiais.com.br/lei/regulamenta-a-atuacao-da-psicologa-no-ambito-do-siste ma-prisional-cfp

Roso, A. (1997). Grupos focais em Psicologia Social: Da teoria à prática. Psico, Porto Alegre, 28, 155-169.

https://www.academia.edu/966182/Grupos_focais_em_psicologia_social_da_teoria_\% C3\%A0_pr\%C3\%A1tica?auto=download

Sani, A. I., \& Gonçalves, R. A. (2007). Estudio empírico sobre las crencias y las percepciones de los niños sobre la violência.

https://www.researchgate.net/profile/Sociedad_Espanola_De_Psicologia_Juridica_Y_Forens e/publication/318723712_Coleccion_Psicologia_y_Ley_n_4_Psicologia_Juridica_Violencia_ y_victimas/links/5979ce7b0f7e9b3bce4f0000/Coleccion-Psicologia-y-Ley-n-4-Psicologia-Jur idica-Violencia-y-victimas.pdf \#page $=61$

Sousa, K. C. S., \& Barros, J. D. V. (2012). Estereótipos étnicos e representações sociais: Uma breve incursão teórica. Revista Educação e Emancipação, 5, 201-226.

http://www.periodicoseletronicos.ufma.br/index.php/reducacaoemancipacao/article/vi ew/3259

Stangor, C. (2012). Stereotypes, Prejudice, and Discrimination. In Social Psychology Principles (Vol. 1, pp. 646-703). London: Lard Bucket. https://2012books.lardbucket.org/pdfs/social-psychology-principles.pdf

Techio, E. M. (2011). Estereótipos sociais como preditores das relações intergrupais. In E. M. Techio, \& M. E. O. Lima (Eds.), Cultura e produção das diferenças: Estereótipos e preconceitos no Brasil, na Espanha e Portugal (pp. 21-76). Brasília: Technopolilitik.

Torres, A. R. R., \& Camino, L. (2013). Grupos Sociais, relações intergrupais e identidade social. In L. Camino, A. R. R. Torres, M. E. O. Lima, \& M. E. Pereira (Eds.), Psicologia Social: Temas e teorias (2nd ed., pp. 515-540). Brasília: Techno Politik.

Trindade, J. (2016). Manual de psicologia jurídica para operadores do direito (7th ed.). Livraria do advogado: Porto Alegre.

Turner, S. (2014). Teoria Social e Neurociência. Tempo Social. Revista de Sociologia da USP, 26, 71-88. http://www.scielo.br/pdf/ts/v26n2/v26n2a05.pdf

https://doi.org/10.1590/S0103-20702014000200005

Valois, L. C. (2016). Direito Penal da Guerra às Drogas (694 p.). Belo Horizonte: D’Plácido. 